\title{
Relationships between oyster mortality patterns and environmental data from monitoring databases along the coasts of France
}

\author{
Patrick Soletchnik ${ }^{1}$, Michel Ropert ${ }^{2}$, Joseph Mazurié ${ }^{3, *}$, \\ Pierre Gildas Fleury ${ }^{3}$, Florence Le $\mathrm{Coz}^{3}$ \\ ${ }^{1}$ IFREMER, Laboratoire Environnement Ressources des Pertuis Charentais. B.P 133, 17390 La Tremblade. \\ France. \\ 2 IFREMER, Laboratoire Environnement Ressources de Normandie \\ 3 IFREMER, Laboratoire Environnement et Ressources Morbihan-Pays de Loire \\ Corresponding author: Joseph.Mazurie@ifremer.fr
}

\begin{abstract}
:
Oyster mortality was monitored at multiple sites along the French coastline ( $\sim 5500 \mathrm{~km}$ ) between 1993 and 2005. Mortality data for one- and two-year-old oysters were collected over 10-12 years in 39 oyster culture sites bordering 3 different "seas": the English Channel, Bay of Biscaye and Mediterranean. Combining these data with records from environmental monitoring databases, 11 of these sites had consistent chronological data sets including both environmental data and mortality records. Mortality in one-year-old oysters was clearly summer mortality ( $49 \%$ of their annual mortality) whereas mortality of two-year-olds occurred mostly in spring (51\%). Analysis of variance revealed that "coastal area" was the main influence on mortality of one-year-olds ( $77.5 \% \%$ of the variance) and that "year studied" was the main influence on mortality of two-year-olds (60.6\% of the variance). The highest mortalities occurred in Marennes and in several sites in Brittany for both age groups, and in Veys Bay (Normandy) for two-year-old oysters only. Environmental parameters were then analysed to investigate which of these might influence summer mortality. Principal Component Analyses revealed that environmental factors such as chlorophyll a (food resource indicator) and salinity (watershed effect) influence oyster mortality. Chlorophyll a concentration (10\% of the variance), water temperature ( $7 \%$ of the variance) and turbidity ( $5 \%$ of the variance) are the main significant factors for the mortality of one-year-olds, while salinity and chlorophyll a have more effect on the mortality of two-year-old oysters (respectively $5 \%$ and $4 \%$ of the variance).
\end{abstract}

Keywords: Pacific oyster; Crassostrea gigas; Environment; Mortality 


\section{Introduction}

Since the beginning of the 1960s, the number of reports of "abnormal" mortality (mortality $>30 \%$ of the population) in the oyster Crassostrea gigas has increased throughout the world (Beattie et al., 1980; Farley, 1992; Imaï et al., 1965; Perdue, 1983; Sinderman, 1976). The first reports of an episode of such mortality were made in Japan and date from as early as 1915 (Takeuchi et al., 1960). The west coast of North America was particularly affected from the 1960 s to the 1980 s, when summer mortality events destroyed up to $60 \%$ of C. gigas livestock (Glude, 1975; Koganezawa, 1975). Severe mortalities in France (affecting more than $30 \%$ of the cultivated population) occurred in Marennes-Oléron Bay in 1976-77 (Heral, et al., 1978), in Arcachon Bay (south-west Atlantic coast) in the 1980s and 1990s (Maurer et al., 1986), in Marennes-Oléron in 1988 (Bodoy et al., 1990) and 1993 (Lodato, 1997), in west Brittany and north-west Normandy in 1994-95 (Goulletquer et al., 1998; Fleury et al., 2001), and in Normandy in 2001 (Costil et al., 2005).

Several causal factors have been proposed to explain summer mortalities: these include water temperature, salinity, "exceptional" climatic conditions (Koganezawa, 1975; Ventilla, 1984). Physiological and/or metabolic disturbances have often been observed to accompany mortality episodes (Mori, 1979; Perdue et al., 1981; Maurer et al., 1986; Soletchnik et al., 2005); mortality events are sometimes associated with the over-maturation of the gonads (Perdue et al., 1981). Eutrophication has been implicated in some cases of mortality (Cho and Kim 1977; Tamate et al., 1965) and many studies recorded a decrease in dissolved oxygen (DO) (Cheney et al., 2000) associated with oyster mortality. Rainfall and floods can also be involved in processes that influence mortality (Bodoy et al, 1990; Calvo et al., 1999): either because of drastic freshwater discharges, which bring about a decrease in DO (Cheney et al., 2000; Cho and Kim, 1977), or because of pollution by solutes or particulate matter carried by this water. In some cases, mortality events are clearly of pathogenic origin (Elston et al., 1987; Meyers et al., 1990; Farley, 1992; Renault et al., 1995; Waechter et al., 2002; Le Roux et al., 2002).

Summer mortalities can affect animals of both one and two years old (Maurer et al., 1986), and both diploids and triploids (Calvo et al., 1999). Different susceptibilities have been 
reported between $C$. gigas stocks from different origins and between different hatchery-bred families (Beattie et al., 1980; Soletchnik et al., 2002; Ernande et al., 2004; Degremont et al., 2005), which indicate there is genetic variability for resistance to summer mortality.

Considered together, these studies indicate that for the most part summer mortalities cannot be explained by a single factor, but rather by the combination of environmental (biotic and abiotic) and internal (genetic, physiological and immunological) parameters. The present study is part of the French national MOREST project on oyster mortality. MOREST attempted from 2002 to 2006 to classify the importance of different factors involved in summer mortalities.

Summer mortalities have been progressively integrated into surveys of oyster culture in France (Bodoy et al, 1990; Le Bec and Mazurié, 1992) and elsewhere in the world (Brown and Hartwick, 1988). In 1992, IFREMER (Institut Français pour la Recherche et l'Exploitation de la MER) merged several of its regional regular surveys into a national monitoring program, REMORA, for coordinated collection of growth and mortality data (Fleury et al., 2001). The REPHY data collection, started in 1984 to protect consumers from toxic algae in seafood, holds records of hydrological parameters that could be valuable for understanding the environmental context of summer mortality episodes (Belin, 1998; Beliaeff et al., 2001).

Biological results obtained from the REMORA database in Brittany from 1993 to 1998 were presented in a previous publication (Fleury et al., 2001). In the present study this approach was broadened, with data collected over a longer time period, 1993-2005, along the entire French coastline. This paper investigates oyster mortality in 9 "Coastal Areas" including 20 "Farming Areas" and 39 experimental "Sites", and considers two age classes: one-year-old oysters (studied since 1995) and two-year-old oysters (studied since 1993). Patterns of mortality are described according to age, site, year and season. Further analysis then combines data from environmental databases (REPHY and Météo France) with data from REMORA, to attempt to identify causal factors. Genetic effects have already been found to account for around $45 \%$ of summer mortality variation in the MOREST experiments (Degremont et al., 2005), this paper aims to investigate how environmental factors influence mortality. 
86

87

\section{Material and methods}

\section{Oyster mortality survey (REMORA) and environmental databanks (REPHY and Méteo France).}

This study examined the environmental factors influencing mortality bringing together mortality data from the REMORA database and environmental data from REPHY and Météo France. The laboratories working on REMORA collect data on oyster rearing performances using the same standardized methods (Fleury et al., 2001). Two oyster groups, the first 7-8 months old ("one-year-old oysters", around $1 \mathrm{~g}$ mean whole weight) and the second 20 months old ("two-year-old oysters", 25-35 g after calibration), were placed in 39 "sites" (Fig 1.) in February of each year (from 1993 to 2005). Each site was stocked with one oyster meshed bag (traditionally used by oyster farmers) for each oyster group. Both age classes were renewed each year: yearling oysters from spat collecting area of Arcachon Bay, and two-year-old oysters from one common site in Brittany, most often the Morbihan Gulf. Oysters were monitored from March (year "n") to April of the following year (year $" n+1 ")$. Three scorings were made per cycle, in June (S1), September (S2) and NovemberDecember (S3), corresponding to spring, summer and autumn (Fleury et al, 2001). At each sampling, mortality was scored by an exhaustive counting of live and dead oysters. This survey covered three different seas (the English Channel, Biscaye Bay from Atlantic ocean and Mediterranean sea). Twenty oyster farming areas were then delimited (according to traditional production basins). Within these 20 farming areas, distributed between latitude $43^{\circ}$ and $50^{\circ}$ North on the French coastline, 39 sites were defined (eg BV01, BV02, and BV03 in the coastal area of Veys bay). Thirty-five of these sites are located within intertidal zones, at levels which are emerged about $20 \%$ of the time. The four other sites remain immersed continually. Three of these were in a Mediterranean lagoon (TH - Fig. 1) and one in a subtidal deep-water oyster culture area in Quiberon Bay (QB02 - Fig. 1). For variance analyses with necessarily replicates, the 39 sites are grouped in 9 coastal areas ecologically coherent (eg. sites $\mathrm{CO} 01, \mathrm{CO} 02, \mathrm{CO} 03$ from west Cotentin are grouped with eastern west Brittany sites (Cancale CA02 and Paimpol PL03); table 1 and Figure 1 and 3). 
The REPHY network has been monitoring phytoplankton and phycotoxins along French coasts since 1984. Its main role is to detect any algal blooming that could become a public health hazard through the consumption of contaminated seafood (Belin, 1998). Every fortnight, at each of the 43 sampling points of the network, phytoplankton species are identified and counted, and measurements are made of water temperature $\left({ }^{\circ} \mathrm{C}\right)$, salinity (PSU), turbidity (NTU), dissolved oxygen (\%), chlorophy $\|$ a $\left(\mu \mathrm{g} \mathrm{L}^{-1}\right)$ and pheophytin $\left(\mu \mathrm{g} \mathrm{L}^{-1}\right)$.

Daily data of air temperature $\left({ }^{\circ} \mathrm{C}\right)$, rainfall $(\mathrm{mm})$, sun exposure (hours) and radiation (Joules per $\mathrm{cm}^{2}$ ) measured at stations close to the different coastal areas of this study were obtained from Météo France.

Monthly values were calculated for all environmental and biological parameters for analysis purpose. Complete temporal series (8-10 years monitoring) were selected from REPHY to be combined with the REMORA data set. Out of the 20 coastal areas studied, only 11 had consistent datasets for both biological and environmental parameters allowing multivariate analyses to be performed (Fig.1 and Table 2).

\section{Parameters of the study}

The spatial scale of the analyses was either site or coastal area. Mortality was measured over spring (S1), summer (S2) and fall (S3) seasons on the same groups of oysters grown in bags. Oyster mortality was calculated per bag as: [(initial number - final number) / initial number] for the seasons $\mathbf{S 1}$, S2 and S3, where initial number was the number in the bag at the start of each season (i.e. the survivors from the previous seasons for S1 and S2). When mortality and environmental data were combined in the second part of the study, the mortality measurement used was that which combined both seasons (S1 + S2). The environmental data set contained monthly averages of water temperature $\left({ }^{\circ} \mathrm{C}\right)$, salinity, turbidity (NTU), dissolved oxygen (\%), chlorophy $\|$ a $\left(\mu \mathrm{L} \mathrm{L}^{-1}\right)$ and pheophytin $\left(\mu \mathrm{g} \mathrm{L}^{-1}\right)$ from the REPHY network and mean air temperature $\left({ }^{\circ} \mathrm{C}\right)$, monthly cumulated rainfalls (mm) and sun exposure (hours) from the Météo France network. 


\section{Statistical analysis}

Environmental and mortality data were log transformed and normalized for statistical analysis. A Principal Component Analysis (PCA) was performed to present hydrological characteristics of 11 farming areas on a monthly basis and over the 12 years. PCAs and linear regressions were performed on non-transformed mortality an environmental data to highlight relations between mortality and environmental parameters. Environmental data were averaged on different periods (ie. whole year centred on winter (September $n-1$ to September n; labelled 9-9), autumn-winter (September n-1 to March n, labelled 9-3), winter (December $n-1$ to March $n$, labelled 12-3), winter-spring (December $n-1$ to June $n$, labelled 12-6), spring (March $\mathrm{n}$ to June $\mathrm{n}$; labelled 3-6), spring-summer (March $\mathrm{n}$ to September $\mathrm{n}$; labelled 3-9) and summer (June $\mathrm{n}$ to September $\mathrm{n}$, labelled 6-9)) to point out the parameter and the period of year which explain the most oyster mortalities. Autumn of the precedent year (from September n-1 to December n-1, 9-12) can not be used because of lack of data. These analyses were performed with the Statgraphic V.5.1 software and the XLStat-Pro v.7.1 software.

\section{Results}

\section{Mortality of the two classes of oysters}

Seasonal effects on mortality

Mortality levels, monitored over the twelve years, for the two age groups, at the 39 rearing sites, are given in Fig. 2. Age had no significant effect on overall mortality levels, which were in the range of $5-14 \%$ for one-year-old oysters and $7-13 \%$ for two-year-olds across all seasons ( $p=0.48$, Table 3$)$. The "season" factor alone had highly significant effect on oyster mortality $(p<0.0001$, Table 3$)$. Mean mortality levels were $2.74 \%( \pm 0.21), 5.31 \%( \pm 0.21)$ and $5.77 \%( \pm 0.21)$ respectively during fall, spring and summer (Table 4$)$. The interaction between age and season was also highly significant, despite the fact that age effect alone was not significant. The highest mortality in one-year-old oysters $(7.26 \%)$ occurred in summer, 
whereas the highest mortality of two-year-old oysters occurred in spring (6.61\%, Table 4). This difference in seasonal mortality with age explains the significant interaction between age and season (Table 3).

\section{3} Effects of location and year on oyster mortality
Analyses of variance were then performed using 9 coastal areas (Fig. 1; Table 1). Effects of "year" and "coastal area" on oyster mortality were thus compared on a finer scale (Table 5). One-year-old oysters were more sensitive to the "coastal area" effect than were two-year-olds. The "coastal area" variance component was $77.5 \%$ for this class of age but only $33.5 \%$ for the two-year-old oysters (Table 5). However, "year" effect accounted for $60.6 \%$ of variance in summer mortality of two-year-old oysters but only $14.5 \%$ in one-yearolds.

$$
\text { For the one-year-old oysters, high mortality values (15-30\%) were mostly }
$$
concentrated at Marennes-Oléron Bay: mortality reached $40 \%$ at the station NMA02 in the central zone of Marennes-Oléron Bay. Mor Bras (QB02, PF02) and North of Finistère (MX02, mortality significantly higher than other sites within this area) have quite elevated mortalities too (Table 6 and Fig.2). In one-year-olds, the lowest mortality rates (ranging from 7.2 to $9 \%$ ) were reached during the years 2000,1996 and 2002 . The highest mortality rate $(17.5 \%)$ was reached in 1995; it was significantly higher than other years $(p<0.05)$.

For two-year-old oysters though, year of rearing appeared to account for the clearest differences in mortality (Fig. 2). In two-year-olds, mortalities encountered in 1999, 1995 and 2000 , ranging from $13.7 \%$ to $19.9 \%$, were significantly higher than in other years $(p<0.05)$ (Table 6). At the other end of the scale, 2002 and 2005 had the lowest mortality rates $(4.4 \%-$ $4.9 \%$ ). Most recent years show moderate levels of mortality (2002 to 2005 are within the five lowest levels of mortality)(Fig. 2). Some sites also seem to be particularly affected, like BV02 (Veys Bay, significantly higher than other sites within Normandy coastal area), NM03 (Poitou-Charentes) and PB02 (significantly higher than other sites within Mor Bras coastal area) (Fig. 2). 
In a few sites, high mortality affected both one- and two-year-old oysters (MX02, PB02; NM03; SM06 and NM01) (Fig. 2). Only in one site though (BV02) was mortality of two-year-olds higher $(28.2 \%)$ than that of one-year-olds $(9.1 \%)$. Many sites did not present high mortalities in either age group: Normano-breton Gulf, Bourgneuf, Arcachon Basin and Thau Lagoon.

\section{Relationships between summer mortalities and environmental conditions}

The mortality results therefore showed the main effects to be "site" and "year" for one and two-year-old oysters respectively. The next step was to analyse the effect of environmental parameters on oyster mortality more precisely in the eleven sites where data was available for both (Table 2).

\section{Environmental characteristics of the coastal areas}

Monthly averages of hydrological and meteorological parameters are shown as box and whisker plots for 11 of the farming areas (Fig. 3). Mean air temperature was around $12^{\circ} \mathrm{C}$ from the English Channel to Brest, and then rose from $13^{\circ} \mathrm{C}$ in South Brittany to $16^{\circ} \mathrm{C}$ on the Thau lagoon (Mediterranean sea) (Fig. 3a). The pattern was almost the same for water temperature (Fig. 3b). Rainfall ranged between 20 and $100 \mathrm{~mm}$ per month (first two quartiles) for all the coastal areas, apart from North of Finistère where rainfall was 60-140 mm (Fig. 3c). Rainfall showed an inverse relationship with sun exposure, which had the lowest number of hours per month (median 120) for the two sites in this area (Morlaix Bay and Brest roadstead). Sun exposure was slightly longer further to the North (Veys Bay and Normano-breton Gulf), but rose up to 180 in the so uth part of the Bay of Biscay, and 220 on the Mediterranean (Fig. 3e). In this latter coastal area, salinity increased up to 40 due to summer evaporation (Fig. 3d). Most Atlantic sites (BR, QB, BO, NMO, SMO, AR), exposed to large fluvial discharges (Loire, Gironde), present typical estuarine cycles with salinity decreasing to 26-28 during winter (at high tide). English Channel sites (CA, PL, MX) at the opposite present higher and more stable salinities (Fig. 3d). Suspended particulate matter 
was gauged via chlorophyll a concentration, turbidity and pheophytin (Fig. 3f, g, h). The highest chlorophyll a concentrations were found in Veys Bay, Brest roadstead, MarennesOléron Bay and Thau lagoon (Fig. 3f). The highest turbidity levels were observed in Bourgneuf Bay, in Marennes-Oléron Bay and in Cancale Bay (Fig. 3g).

A Principal Component Analysis (PCA) was used to display mean monthly hydrological change in the coastal areas (Fig. 4). Morlaix river (MX) and the bays of Paimpol (PL) and Cancale (CA) in North Brittany, and Quiberon Bay (QB) in South Brittany all presented a similar pattern with a low chlorophyll $a$ and pheophytin concentration in the water throughout the year (group 1). Monthly values were mainly distributed along the first axis of temperature, salinity and turbidity, showing a slight increase in temperature and salinity from January to July-August and a decrease during fall and early winter. Arcachon basin (AR) showed a similar pattern, but with a higher level of chlorophyll a and pheophytin (group 2). Thau lagoon (TH) was characterized by the highest summer temperature and salinity (group 3). High seasonal change in salinity occurred in the Bourgneuf Bay (BO) (group 4), and in MarennesOléron Bay (SM and NM) (group 5) where it was associated with the spring bloom (chlorophyll a increase). Brest roadsted (BR) and Veys Bay (BV) were characterized by high chlorophyll a seasonality in a low range of salinity (group 6).

Two Principal Component Analyses (PCAs), one for each age group, were performed with the same set of data (11 sites along the French coast where environmental and mortality data are available on the 1993-2005 period, Table 2) and revealed relationships between some environmental conditions and oysters mortality.

Environmental data used in these PCAs are chlorophyll a (CHLOROA), pheophytin (PHEO) and turbidity (TURB) to stand for availability and level of trophic resource, water temperature (TEMP) and then salinity (SALI) to account for freshwater inputs on the rearing site, with different means (table 7 and figure 5).

One-year-old oysters mortality is significantly linked to chlorophyll a level of summer (6-9, $12 \%$ variability explained), spring-summer (3-9, 9\% variability explained), whole year centred 
on winter $(9-9,8 \%$ variability explained) and autumn-winter $(9-3,6 \%$ variability explained). It is significantly linked to water temperature too, especially with the one of spring-summer (3$9,7 \%$ variability explained), spring (3-6, $6 \%$ variability explained), winter-spring $(12-6,5 \%$ variability explained) and whole year centred on winter (9-9,5\% variability explained). It is signific antly linked to summer turbidity level too $(6-9,5 \%$ variability explained).

Two-year-old oysters mortality is significantly inversely linked to autumn-winter salinity (9-3, $5 \%$ variability explained) and to autumn-winter chlorophyll a level (4\% variability explained).

Using the same parameters as used in the PCAs linear models can be adjusted with the progressive regression procedure (XL-StatPro v. 7.1) to point out the best parameter to explain oysters mortality (table 8).

Model equation for one-y ear-old oysters spring and summer mortality (1y-SSM):

$$
1 \mathrm{y}-\mathrm{SSM}=7,54.10^{-02}+1,75.10^{-02} \text { CHLOROA 6-9 }
$$

Model equation for two-year-old oysters spring and summer mortality (2y-SSM):

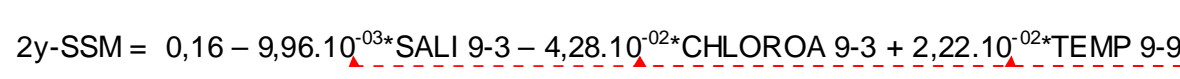

These models are both significant $(p<0.05)$ and they respectively explain $11.9 \%$ and $16.3 \%$ of mortality variability.

A polynomial model has been tested on one-year-olds mortality data versus CHLOROA 6-9 to test the hypothesis that a lack of chlorophyll a in summer could be a factor of mortality. This model is significant $(p<0.05)$ and explain $16.2 \%$ of mortality variability.

For the one-year-old oysters, the strongest parameters responsible for mortality seems to be the one of spring-summer period (level of chlorophyll a, turbidity and temperature); for the two-year-old oysters, the low salinity measurements of the autumn-winter period seems to be the strongest parameter linked to oysters mortality; The two "models" of one-year-old and two-year-old oysters mortality are quite different regarding the period concerned for the effect (spring-summer for the one-year-old oysters 
and previous autumn-winter for the two-year-old oysters), and the parameters responsible for mortality (eg. level of chlorophy II a, water temperature and turbidity for one-year-old oysters, and salinity, water temperature and chlorophyll a (as a reducer of mortality) for twoyear-olds).

\section{Discussion}

Oyster mortalities have often been attributed to "summer mortality" phenomena (Arakawa et al., 1971; Beattie et al., 1980; Cheney et al., 1998; Maurer and Comps, 1986). The present survey provides a better understanding of these events along the French coasts because mortality was monitored in spring, summer and fall. Most oyster mortalities ( $80 \%)$ occurred during the spring-summer period. A significant difference was observed between "spring" mortality of two-year-old oysters and "summer" mortality of one-year-old oysters. Differences in levels and periods of mortality between the age groups might be due to an effect of the maturation process, which influences summer mortality and is age-dependent (Maurer and Comps, 1986; Mori, 1979).

In this study, only $6 \%$ of the data points from juveniles showed mortality over $30 \%$. The worst sites for "chronic" summer mortality of "juveniles" (one-year-olds) in the study were in Marennes-Oléron Bay. Mor Bras was also heavily affected, with mortalities in the Gulf of Morbihan, Quiberon Bay and Vilaine estuary. Bay of Morlaix was also affected. For two-year-old oysters, mortalities up to $30 \%$ were confined to $2 \%$ of the data points recorded during the survey. Globally, the same sites were concerned as for the mortality of one year olds, with Veys Bay (BV02) in addition.

Temperature is the environmental parameter most frequently implicated in mortality events (Cheney et al., 2000; Friedman et al., 1997; Lipovsky and Chew, 1972; Meyers et al., 1990; Shafee and Sabatie, 1986), even if no direct relationship has been established. In this study, water temperature is significantly linked to one-year-old oyster mortality on different periods of year, principally in spring-summer, even if this correlation does not explain much of the mortality variability; water temperature effect can be understood through its action on sexual maturation (which could weaken oysters towards stresses), or as a factor of stress. 
On the other hand, the intensity of oyster summer mortalities was not related to the positive north-south thermal gradient along the French coastline. Water temperatures in Thau lagoon on the Mediterranean coast rose as high as $28-30^{\circ} \mathrm{C}$ without any lethal consequence. Middle latitude sites in the gulf of Biscay were much more affected by oyster summer mortalities than those to the north or south, which confirms that temperature is not the only causal factor. This shows the need for specific investigations in each coastal area and for a comparative typology study, to provide a better understanding of the summer mortality phenomenon.

High trophic level has sometimes been suspected to contribute to summer mortality events in laboratory experiments (Lipovsky and Chew, 1972) or those made in the field (Tamate et al., 1965). Chlorophyll a is often considered as a trophic resource indicator (Cigarria, 1999; Heral et al., 1984; Soletchnik et al., 1996). This effect is probably related to the investment of energy from trophic resources into sexual maturation. For example, a comparison was made in Japan between the oligotrophic Onagawa Bay, where summer mortalities was negligible, and the eutrophic Matsushima Bay, where over-maturation of oocytes led to physiological and metabolic disorders inducing high mortality (Mori et al., 1965; Tamate et al., 1965). In the present study, summer chlorophyll a level showed a slight but significant correlation with juvenile mortality rate. Even though only a small amount of the variability was explained by chlorophyll a levels, this path should be investigated so as to understand how this food resource indicator can have a negative effect on survival of oneyear-old oysters, and which period of year is the most "risky". Chlorophyll a of the autumnwinter period is significantly linked to two-year-old oysters mortality, but inversely; a lack of food in autumn-winter could provoke a physiologic weakness at the beginning of spring that could enhance the stress due to sexual maturation. Previous analysis of REMORA and REPHY data had identified lowered pheophytin level as a factor involved in juvenile mortality. Heral et al., (1984) showed that food requirement differed between one- and twoyear-old oysters. Growth correlated better with pheophytin in one-year-olds and better with chlorophyll a in two-year-olds.

A low autumn-winter salinity tended to enhance mortalities in this study, as a reflect of rainfall and watershed discharge that happened during these seasons. It was specially 
implicated in some mortalities of two-year-olds in ecosystems strongly influenced by river plumes. Freshwater discharge constitutes a stress factor or transports anthropic pollution (Menesguen, 1992). Two hypothesis can be put forth: a toxicity of the freshwater discharged in the farming areas, that would weaken oysters making them more sensitive to stresses during spring-summer period, or an effect through the trophic resource which production could be enhanced by inputs of nutrients. In France, susceptible sites showing more than $15 \%$ mortality of cupped oysters, such as Veys Bay, Morlaix Bay, Pen Bé and Penerf bays are directly influenced by river plumes. Some of these sites have already suffered oyster mortality crises, like Pen Bé marked by 30\% mortality in 1988 and 1989 which reached 55\% in the inner part of the bay (Mazurié pers. com.). Terrestrial pollution was suspected to be a likely cause in this case. Further south, Marennes-Oléron Bay also had a high mortality crisis in 1988 with estimated losses up to $7,800 \mathrm{t}$ (Bodoy et al., 1990). Although pathological and toxicological analyses were made, none identified a probable cause. However exceptional rainfall was recorded at this time, accompanied by high temperatures and a delay in the seasonality of phytoplanktonic blooms (Bodoy et al., 1990). Exceptional floods and high temperatures were also implicated in mortality of Ostrea edulis during summer 1997 (Calvo et al., 1999). In Veys Bay, freshwater discharges include intense and short term discharges which go beyond the normal scale of measurement and are thus not properly shown by hydrological recordings made in this area (Costil et al., 2005). This example highlights the importance of scaling and the need for correct spatio-temporal sampling in these ecosystems. The English Channel coast (apart from Veys Bay) sites which are little influenced by freshwater discharge did not suffer significant summer mortalities. However Bourgneuf Bay (Loire influence) presented seasonal freshening (low salinity) without enduring mortality events. Geographical mapping of mortality was therefore not directly related to river influences. In south-west Florida Water management practices have drastically altered natural water quality conditions within estuaries by affecting salinity and nutrient influx (Savarese and Volety, 2001). The eastern oyster, Crassostrea virginica, is used as an indicator of ecosystem health in this area to establish target water quality conditions for restoration efforts (Savarese and Volety, 2001). 
Seasonal occurrence of mortality and effects of location and year were all dependent on the age of the oysters in this study. Over the twelve years of mortality monitoring, 1995 and 1999 (years of high mortality) contrasted with 1993 and recent years (2002-2005) (years of low mortality along the French coastline), due to interannual differences in meteorological and hydrological conditions. However these conditions also interacted with the spatial scale of the survey. Whatever the geographic scale considered, mortality differed between sites always being higher in certain: Veys Bay, Morlaix Bay, several sites in Mor Bras (Auray River, Quiberon Bay, Penbé Bay), and Marennes-Oléron Bay. A simple typology developed from hydrological parameters in the farming areas did not isolate any specific pattern that would identify a "risky" ecosystem for oyster culture. However, locations on the Normanobreton Gulf, which had lower variations in their temperature cycles and lower freshwater input, were less affected by mortality events.

On a worldwide scale, the reason for summer mortalities has been identified as a complex of multiple stress factors acting together to induce physiological disorders and metabolic disturbance (Tamate et al., 1965; Cheney et al., 2000). Mortality events result from combined factors in a different manner from one ecosystem to another. The models obtained from the present study, despite the low amount of variability explained, allow some general trends to be derived for this first integrated study of oyster mortality over the whole French coastline. They point out the fact that the environmental factors responsible for oysters mortality are different according to age of oysters, probably in relation with metabolic differences between the two ages. They also open paths for further investigation, including research into additional stress parameters which could bring about mortality events.

\section{Acknowledgements}

We thank METEO-FRANCE for generously providing some of the data used in this paper, as well as the Ifremer staff regularly involved in environmental and shellfish networks: REPHY and REMORA. We would also like to thank $\mathrm{Dr} \mathrm{H}$. McCombie for reviewing the English in this paper. This work was supported by the MOREST national project funded by IFREMER; by 
412 Arakawa, K.Y., Kusuki, Y., Kamigaki, M., 1971. Studies on biodeposition in oyster beds. I.

413 Economic density for oyster culture. Venus 30, 113-128.

414 Beattie, J.H., Chew, K.K., Hershberger, W.K., 1980. Differential survival of selected strains of 415 Pacific oysters C. gigas during summer mortality. Proc. Nat. Shellfish Assoc. 70, 119-125.

416 Beliaeff, B., Gros, P., Belin, C., Raffin, B., Gailbard, I., Durbec, J., 2001. Phytoplankton events 417 in French coastal waters during 1987-1997. Oceanologica Acta 24, 425-433.

418 Belin, C., 1998. French phytoplankton monitoring: an exploration of optimum data presentation. 419 ICES Journal of Marine Science 55, 705-710.

420 Bodoy, A., Garnier, J., Razet, D., Geairon, P. 1990. Mass mortalities of oysters (Crassostrea 421 gigas) during spring 1988 in the bay of Marennes-Oleron, related to environmental 422 conditions, CIEM Copenhagen C.M. K/11, 23 pp.

423 Brown, J.R., Hartwick, E.B., 1988. Influences of temperature, salinity and available food upon 424 suspended culture of the Pacific oyster, Crassostrea gigas. 2. Condition index and survival. 425 Aquaculture 70, 253-267.

426 Calvo, G.W., Luckenbach, M.W., Allen, S.K., Jr., Burreson, E.M., 1999. Comparative field 427 study of Crassostrea gigas (Thunberg, 1793) and Crassostrea virginica (Gmelin, 1791) in 428 relation to salinity in Virginia. J. Shell. Res. 18, 465-473.

429 Cheney, D.P., Elston, R., MacDonald, B., 1998. Summer mortality in Pacific oyster: 430 Observations on the influences of water quality and culture methods. J. Shell. Res. 17, p 4.

431 Cheney, D.P., Macdonald, B.F., Elston, R.A., 2000. Summer mortality of Pacific oysters, 432 Crassostrea gigas (Thunberg): Initial findings on multiple environmental stressors in Puget 433 Sound, Washington, 1998. J. Shell. Res. 19, 353-359. 
434 Cho, C.H., Kim, Y.S., 1977. Microenvironment in oyster farm area. 1. On the eutrophication and 435 raft density in Geoje Bay. Bull. Kor. Fish. Soc. 10, 259-265.

436 Cigarria, J., 1999. Effects of age, size, and season on growth of soft tissue in the oyster 437 Crassostrea gigas (Thunberg, 1793). J. Shell. Res. 18, 127-131.

438 Costil, K., Royer, J., Ropert, M., Soletchnik, P. Mathieu, M., 2005. Spatio-temporal variations in 439 biological performances and summer mortality of the Pacific oyster Crassostrea gigas in 440 Normandy (France). Helg. Mar. Res. 59, 286-300.

441 Degremont, L., Bedier, E., Soletchnik, P., Ropert, M., Huvet, A., Moal, J., Samain, J.F., Boudry, 442 P., 2005. Relative importance of family, site, and field placement timing on survival, growth, 443 and yield of hatchery-produced Pacific oyster spat (Crassostrea gigas). Aquaculture 249, $444 \quad 213-229$

445 Elston, R.A., Beattie, J.H., Friedman, C., Hedrick, R., Kent, M.L., 1987. Pathology and 446 significance of fatal inflammatory bacteraemia in the Pacific oyster, Crassostrea gigas 447 Thunberg. J. Fish Dis. 10, 121-132.

448 Ernande, B., Boudry, P., Clobert, J., Haure, J., 2004. Plasticity in resource allocation based life 449 history traits in the Pacific oyster, Crassostrea gigas. I Spatial variation in fund abundance. J. $450 \quad$ Evol. Biol. 17, 342-356.

451 Farley, C.G., 1992. Mass mortalities and infectious lethal diseases in bivalve molluscs and 452 association with geographic transfers of populations. In: Rosenfield, A., Mann, R (Ed.), 453 Dispersal of living organisms into aquatic ecosystems. Maryland Sea Grant Publishers, 454 College Park, Maryland, pp. 139-155.

455 Fleury, P., Goyard, E., Mazurie, J., Claude, S., Bouget, J., Langlade, A., Le Coguic, Y., 2001. 456 The assessing of Pacific oyster (Crassostrea gigas) rearing performances by the 457 IFREMER/REMORA network: method and first results (1993-98) in Brittany (France). 458 Hydrobiologia 465, 1-3.

459 Friedman, C.S., Shamseldin, A., Pillai, M., Olin, P.G., Cherr, G.N., Jackson, S.A., Rifkin, E., 460 Uhlinger, K.R., Clegg, J.S., 1997. Summer mortality and the stress response of the Pacific 461 oyster, Crassostrea gigas Thunberg. J. Shell. Res. 16, 335.

462 Gailhard, I., Durbec, J.P., Beliaeff, B. \& Sabatier, R. (2003) Phytoplankton ecology along 463 French coasts: inter-site comparison. Comptes rendus Biologies 326, 853-863. 
464 Glude, J.B., 1975. A summary report of Pacific coast oyster mortality investigations 1965-1972, 465 the Third U.S.-Japan Meeting on Aquaculture, Tokyo, Japan, pp. 1-28.

466 Goulletquer, P., Soletchnik, P., Le Moine, O., Razet, D., Geairon, P., Faury, N., Taillade, S., 467 1998. Summer mortality of the Pacific cupped oyster Crassostrea gigas in the bay of 468 Marennes-Oleron (France). ICES, Lisbon CM/14, pp. 14-20.

469 Heral, M., Berthome, J.P., Razet, D., Garnier, J., 1978. Hydrobiological study of the Marennes470 Oleron basin. An example: the drought during summer 1976. Rev. Trav. Inst. Peches Marit. $471 \quad$ Nantes 42, 269-290.

472 Heral, M., Deslous-Paoli, J.M., Razet, D., Prou, J., 1984. An attempt to corelate in situ biotic 473 and abiotic factors of water and of the water-sediment interface with the production of the 474 oyster Crassostrea gigas. Oceanis 10, 465-475.

475 Imaï, T., Numachi, K., Oizumi, J., Sato, S., 1965. Studies on the mass mortality of the oyster in 476 Matsushima Bay. II. Search for the cause of mass mortality and possibility to prevent it by 477 transplantation experiment. Bull. Tohoku reg. Fish. Res. Lab. 25, 27-38.

478 Koganezawa, A., 1975. Present status of studies on the mass mortality of cultured oysters in 479 Japan and its prevention, Proceedings of the Third U.S.-Japan Meeting on Aquaculture, 480 Tokyo, Japan, pp. 29-34.

481 Le Bec C., Mazurié J., 1992. Croissance de Crassostrea gigas en Bretagne en 1989, mise en 482 place d'un réseau d'acquisition de données. Haliotis 22, 61-70.

483 Le Roux, F., Gay, M., Lambert, C., Waechter, M., Poubalanne, S., Chollet, B., Nicolas, J.L., 484 Berthe, F., 2002. Comparative analysis of Vibrio splendidus related strains isolated during 485 Crassostrea gigas mortality events. Aquat. Living Res. 15, 251-258.

486 Lipovsky, V.P., Chew, K.K., 1972. Mortality of Pacific oysters (Crassostrea gigas): the influence 487 of temperature and enriched seawater on oyster survival. Proc. Natl. Shellfish. Assoc. 62, $488 \quad 72-72$.

489 Lodato, M.I., 1997. [Spring mortality of Crassostrea gigas in the oyster reefs at Perquis and 490 Ronce (France, Bay of de Marennes-Oleron): Study of oyster rearing methodologies and 491 biological and spatial characteristics. Thesis of the Ecole Natl. Veterinaire, Nantes (France), 492 pp. 127. 
493 Maurer, D., Comps, M., 1986. Summer mortalities of oysters Crassostrea gigas in the Bay of 494 Arcachon: Environmental, biochemical, and histological aspects. In: Pathology in Marine 495 Aquaculture (Pathologie en aquaculture marine). Vivarès, C. P., Bonami, J. R., Jaspers, E. 496 (Eds). European Aquaculture Society, Bredene, Special Publication 9, 29-42 pp.

497 Maurer, D., Comps, M., His, E., 1986. Caractéristiques des mortalités printanières de l'huître 498 Crassostrea gigas dans le Bassin d'Arcachon. Haliotis 15, 309-317.

499 Menesguen, A, 1992. Les problèmes d'eutrophisation littorale et leur modélisation. Hydroécol. $500 \quad$ Appl. 2, 55-77.

501 Meyers, T.R., Short, S., Eaton, W., 1990. Summer mortalities and incidental parasitisms of 502 cultured Pacific oysters in Alaska. J. Aquat. Anim. Health. 2, 172-176.

503 Mori, K., 1979. Effects of artificial eutrophication on the metabolism of the Japanese oyster 504 Crassostrea gigas. Mar. Biol. 53, 361-369.

505 Perdue, J.A., 1983. The relationship between the gametogenic cycle of the Pacific oyster, $C$. 506 gigas, and the summer mortality phenomenon in strains of selectively bred oysters. Ph.D. 507 University Microfilms International, . Washington Univ., Seattle (USA), 205 pp.

508 Perdue, J.A., Beattie, J.H., Chew, K.K., 1981. Some relationships between gametogenic cycle 509 and summer mortality phenomenon in the Pacific oyster (Crassostrea gigas) in Washington 510 State. J. Shell. Res. 1, 9-16.

511 Renault, T., Le Deuff, R.M., Cochennec, N., Chollet, B., Maffart, P., 1995. Herpes-like viruses 512 associated with high mortality levels in larvae and spat of Pacific oysters, Crassostrea gigas: 513 A comparative study, the thermal effects on virus detection in hatchery-reared larvae, 514 reproduction of the disease in axenic larvae. Vet. Res. 26, 539-543.

515 Savarese, M., Volety, A.K., 2001. Impact of waterflow alteration upon oyster growth and 516 distribution within estuaries of southwest Florida: implications for management and 517 restoration. Aquaculture 2001: Book of Abstracts. p. 578.

518 Shafee, M.S., Sabatie, M.R., 1986. Growth and mortality of Pacific oysters in Oualidia lagoon 519 (Morocco). Aquaculture 53, 201-214.

520 Sinderman, C.J., 1976. Oyster mortalities and their control. In: Pillay, T.V.R., Dill, W.M. (Eds.), 521 Advances in Aquaculture. Fishing News Brooks Farnham Publishers, England, pp. 349-361. 
522 Snedecor, G.W; Cochran, W.G., 1989. Statistical Methods, lowa State University Press, Ames, 523 503pp.

524 Soletchnik, P., Goulletquer, P., Heral, M., Razet, D., Geairon, P., 1996. Evaluation of the 525 energetic budget of the Japanese oyster, Crassostrea gigas in Marennes-Oleron Bay 526 (France). Aquat. Living Resour. 9, 65-73.

527 Soletchnik, P., Huvet, A., Le Moine, O., Razet, D., Geairon, P., Faury, N., Goulletquer, P., 528 Boudry, P., 2002. A comparative field study of growth, survival and reproduction of 529 Crassostrea gigas, C. angulata and their hybrids. Aquat. Living Resour. 15, 243-250.

530 Soletchnik, P., Lambert, C., Costil, K., 2005. Summer Mortality of Crassostrea gigas 531 (Thunberg) in relation to environmental rearing conditions. Aquat. Living Resour. 24, 197532208.

533 Takeuchi, T., Takemoto, Y., Matsubara, T., 1960. Haematological study of bacterial affected 534 oysters. Rep. Hiroshima Prefect. Fish. Exp. Stn. 22, 1-7.

535 Tamate, H., Numachi, K.-i., Mori, K., Itikawa, O., Imai, T., 1965. Studies on the Mass Mortality 536 of the Oyster in Matsushima Bay. VI - Pathological Studies. Bull. Tohoku Reg. Fish. Res. 537 Lab. 25, 89-104.

538 Ventilla, R.F., 1984. Recent developments in the Japanese oyster culture industry. Adv. Mar. 539 Biol. 21, 2-54.

540 Waechter, M., Le Roux, F., Nicolas, J.L., Marissal, E., Berthe, F., 2002. Characterisation of 541 Crassostrea gigas spat pathogenic bacteria. C. R. Biol. 325, 231-238. 


\section{Tables}

Table 1. REMORA Network : 39 experimental sites references in 20 Farming Areas and 9 Coastal Areas along the French coasts. Bold types written coastal areas and sites are those combining mortality and environmental data bank.

Table 2. Hydrological (REPHY network) and meteorological (Météo France network) reference stations for the coastal areas defined from the REMORA network.

Table 3. Analyses of variance: mean squares, $P$ values and variance components for the effects of age and season on mortality of one and two-year-old oysters.

Table 4. Mortality mean and standard error per Age group and Season.

Table 5. Analyses of variance: mean squares, $\mathrm{P}$ values and variance components for effects of site and year on mortality of one and two-year-old oysters.

Table 6. Mortality means and standard errors (SE) per Coastal Area for one-year-old oysters and per Year for two-year-old oysters.

Table 7. Extracts from the correlation matrix of the Principal Component Analyses performed on mortality and environmental data ; 1y-SSM stands for 1-year-old oyster spring and summer mortality; 2y-SSM stands for 2-year-old oyster spring and summer mortality.

Table 8 : Linear models analyses : $\mathrm{R}^{2}$, significance and parameters analyses and estimations and equation for two and one-year-old oysters summer mortality ; 1y-SSM stands for 1-yearold oyster spring and summer mortality; 2y-SSM stands for 2-year-old oyster spring and summer mortality. 
Table 1

\begin{tabular}{|c|c|c|}
\hline Coastal area & Farming area & Sites \\
\hline \multirow{2}{*}{ Normandy (N) } & Veys bay (BV) & BV01; BV02; BV03 \\
\hline & Saint Vast-La-Hougue bay (SV) & SV01; SV02;;SV03 \\
\hline \multirow{3}{*}{ Normano-breton Gulf (GNB) } & West of Cotentin (CO) & $\mathrm{CO} 01 ; \mathrm{CO} 02 ; \mathrm{CO} 03$ \\
\hline & Cancale bay (C A) & $\mathrm{CAO2}$ \\
\hline & Paimpol bay (PL) & PL03 \\
\hline \multirow{3}{*}{ North of Finistère $(\mathrm{FN})$} & Morlaix bay (MX) & MX02 \\
\hline & Aber Benoit (AB) & AB02 \\
\hline & Brest roadstead (BR) & BR03 \\
\hline \multirow[t]{3}{*}{ Not used } & Etel river $(E L)$ & EL02 \\
\hline & Quiberon bay (QB) & QB01; QB02 \\
\hline & Auray river ( $\mathrm{AY}$ ) & AY02 \\
\hline \multirow[t]{3}{*}{ Mor Bras (MB) } & Gulf of Morbihan (GM) & GM02 \\
\hline & Penerf bay (PF) & PF02 \\
\hline & Pen-Bé bay (PB) & PB02 \\
\hline Pays de Loire (PL) & Bourgneuf bay (BO) & $\mathrm{BO} 1 ;$ BO02; $\mathrm{BO} 03 ; \mathrm{BO} 04$ \\
\hline Ré Island (RE) & Ré island (RE) & RE01; RE02 \\
\hline \multirow{2}{*}{ Marennes-Oléron bay (MA) } & $\begin{array}{l}\text { North part of Mare nne s-Oléron } \\
\text { bay (NM) }\end{array}$ & NM01; NM02; NM03 \\
\hline & $\begin{array}{c}\begin{array}{c}\text { South part of Marenne s-Oléron } \\
\text { bay(SM) }\end{array} \\
\end{array}$ & SM04; SM05; SM06 \\
\hline Aquitaine $(A Q)$ & Arcachon basin (AR) & AR01; AR02; AR03 \\
\hline Mediterranean coest (ME) & Thau lagoon(TH) & TH01; TH02; TH03 \\
\hline
\end{tabular}


Table 2

\begin{tabular}{clcc}
\hline $\begin{array}{c}\text { Farming area } \\
\text { (from North to South) }\end{array}$ & Roches de Grandcamp & $\begin{array}{c}\text { Hydrology - } \\
\text { reference station } \\
\text { reference station }\end{array}$ \\
\hline $\begin{array}{c}\text { Veys Bay } \\
\text { Cancale Bay }\end{array}$ & BV & Cancale nord & Din-PeB-BV \\
Paimpol Bay & PL & Bréhat \\
Morlaix Bay & MX & Pen al Lann & Saint Brieuc \\
Brest Roadstead & BR & Lanvéoc & Landivisiau \\
Quiberon Bay & QB & Men er Roue & Vannes \\
Bourgneuf bay & BO & Bois de la Chaise & Bourgneuf \\
North Marennes-Oléron bay & NMA & Boyard & La Rochelle \\
South Marennes-Oléron bay & SMA & Auger & La Rochelle \\
Arcachon Basin & AR & Teychan & Cap Ferret \\
Thau lagoon & TH & Bouzigues & Montpellier \\
\hline
\end{tabular}


Table 3

\begin{tabular}{lcccc}
\hline Source & $D f$ & Mortality & & \\
\cline { 3 - 5 } & & Mean squares & $P$ value & $\begin{array}{c}\text { Variance } \\
\text { Component (\%) }\end{array}$ \\
\hline Age & 1 & 0.007 & 0.4857 & 0.4 \\
season & 2 & 0.971 & 0.0000 & 51.2 \\
Age x Season & 2 & 0.904 & 0.0000 & 47.7 \\
residual & 30 & 0.013 & & 0.7 \\
\hline
\end{tabular}


Table 4

\begin{tabular}{|c|c|c|c|c|c|}
\hline Age & Season & $\mathrm{N}$ & Mortality & \multicolumn{2}{|c|}{ Groups* } \\
\hline \multirow[t]{3}{*}{1} & Spring & 311 & $4.02 \pm 0.31$ & & \\
\hline & Summer & 311 & $7.26 \pm 0.32$ & & * \\
\hline & Autumn & 309 & $3.50 \pm 0.32$ & * & \\
\hline \multirow[t]{3}{*}{2} & Spring & 410 & $6.61 \pm 0.28$ & & * \\
\hline & Summer & 406 & $4.28 \pm 0.28$ & & * \\
\hline & Autumn & 408 & $1.98 \pm 0.28$ & * & \\
\hline 1 & All seasons & 931 & $4.92 \pm 0.18$ & $*$ & \\
\hline 2 & All seasons & 1224 & $4.29 \pm 0.16$ & * & \\
\hline \multirow[t]{3}{*}{ All ages } & Spring & 721 & $5.31 \pm 0.21$ & & 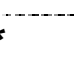 \\
\hline & Summer & 717 & $5.77 \pm 0.21$ & & * \\
\hline & Autumn & 717 & $2.74 \pm 0.21$ & * & \\
\hline
\end{tabular}

*Bonferroni tests (Statgraphic V.5) were performed to distinguish significantly different groups $(p<0.05)$. 
Table 5

\begin{tabular}{clcccc}
\hline \multirow{2}{*}{ Age } & \multicolumn{1}{c}{ Source } & $\mathrm{df}$ & \multicolumn{2}{c}{ Mortality } & \\
\cline { 3 - 6 } & & & Mean square & $\mathrm{Pr}>\mathrm{F}$ & Variance component (\%) \\
\hline 1 year old & Coastal Area & 7 & 0.820 & $<0.0001$ & $77.5 \%$ \\
& Year & 10 & 0.153 & $<0.0001$ & $14.5 \%$ \\
& Coastal Area*Year & 70 & 0.050 & 0.015 & $4.8 \%$ \\
& Error & 264 & 0.034 & & $3.2 \%$ \\
\hline 2 years old & Coastal Area & 8 & 0.261 & $<0.0001$ & $33.5 \%$ \\
& Year & 12 & 0.472 & $<0.0001$ & $60.6 \%$ \\
& Coastal Area*Year & 96 & 0.026 & 0.063 & $3.3 \%$ \\
& Error & 351 & 0.020 & & $2.6 \%$ \\
\hline
\end{tabular}


Table 6

\begin{tabular}{|c|c|c|c|c|c|c|c|c|}
\hline Age & Coastal area & $\mathrm{N}$ & Mortality & $\mathrm{SE}$ & & Groups $^{*}$ & & \\
\hline \multirow[t]{8}{*}{1 year old } & MA & 63 & 0.225 & 0.017 & * & & & \\
\hline & MB & 60 & 0.132 & 0.014 & & * & & \\
\hline & $\mathrm{FN}$ & 30 & 0.107 & 0.017 & & * & * & \\
\hline & RE & 20 & 0.105 & 0.016 & & * & * & \\
\hline & $A Q$ & 22 & 0.089 & 0.018 & & & * & * \\
\hline & GNB & 55 & 0.078 & 0.009 & & & * & * \\
\hline & PL & 42 & 0.065 & 0.007 & & & & * \\
\hline & $\mathrm{N}$ & 60 & 0.061 & 0.006 & & & & * \\
\hline
\end{tabular}

\begin{tabular}{|c|c|c|c|c|c|c|c|c|c|c|c|c|c|}
\hline \multirow{14}{*}{$\frac{\text { Age }}{2 \text { years old }}$} & Year & $\mathrm{N}$ & Mortality & SE & \multicolumn{9}{|c|}{ Groups } \\
\hline & 1999 & 35 & 0.199 & 0.018 & * & & & & & & & & \\
\hline & 1995 & 37 & 0.174 & 0.016 & * & * & & & & & & & \\
\hline & 2000 & 37 & 0.137 & 0.009 & & * & & & & & & & \\
\hline & 1994 & 36 & 0.113 & 0.013 & & & * & & & & & & \\
\hline & 1997 & 36 & 0.096 & 0.012 & & & * & * & & & & & \\
\hline & 2001 & 36 & 0.096 & 0.009 & & & * & * & & & & & \\
\hline & 1998 & 36 & 0.090 & 0.013 & & & * & * & * & & & & \\
\hline & 1996 & 37 & 0.082 & 0.007 & & & & * & * & * & & & \\
\hline & 2004 & 36 & 0.078 & 0.014 & & & & & * & * & * & & \\
\hline & 1993 & 35 & 0.065 & 0.007 & & & & & & * & * & * & \\
\hline & 2003 & 36 & 0.056 & 0.008 & & & & & & & * & * & * \\
\hline & 2005 & 34 & 0.049 & 0.004 & & & & & & & & * & * \\
\hline & 2002 & 36 & 0.044 & 0.005 & & & & & & & & & * \\
\hline
\end{tabular}

*Least Significance Difference tests (LSD; XLStatPro 7.1) were performed. Groups were significantly defined at $p<0.05$ level 
Table 7

\begin{tabular}{lr}
\hline Correlation matrix & \multicolumn{1}{c}{ 1y-SSM } \\
\hline 1y-SSM & 1 \\
CHLOROA 9-9 & $\mathbf{0 . 2 9 0}$ \\
PHEO 9-9 & -0.020 \\
SALI 9-9 & -0.137 \\
TEMP 9-9 & $\mathbf{0 . 2 2 1}$ \\
TURB 9-9 & 0.170 \\
CHLOROA 3-6 & 0.153 \\
PHEO 3-6 & -0.150 \\
SALI 3-6 & -0.125 \\
TEMP 3-6 & $\mathbf{0 . 2 4 4}$ \\
TURB 3-6 & 0.166 \\
CHLOROA 3-9 & $\mathbf{0 . 3 0 4}$ \\
PHEO 3-9 & -0.183 \\
SALI 3-9 & -0.108 \\
TEMP 3-9 & $\mathbf{0 . 2 6 6}$ \\
TURB 3-9 & 0.176 \\
CHLOROA 12-6 & 0.154 \\
PHEO 12-6 & -0.121 \\
SALI 12-6 & -0.131 \\
TEMP 12-6 & $\mathbf{0 . 2 3 4}$ \\
TURB 12-6 & 0.148 \\
CHLOROA 6-9 & $\mathbf{0 . 3 4 6}$ \\
PHEO 6-9 & -0.180 \\
SALI 6-9 & -0.070 \\
TEMP 6-9 & 0.202 \\
TURB 6-9 & $\mathbf{0 . 2 1 7}$ \\
CHLOROA 9-3 & $\mathbf{0 . 2 3 8}$ \\
PHEO 9-3 & 0.069 \\
SALI 9-3 & -0.154 \\
TEMP 9-3 & 0.132 \\
TURB 9-3 & 0.157 \\
CHLOROA 12-3 & 0.204 \\
PHEO 12-3 & -0.061 \\
SALI 12-3 & -0.168 \\
TEMP 12-3 & 0.186 \\
TURB 12-3 & 0.116 \\
\hline &
\end{tabular}

\begin{tabular}{lr}
\hline Correlation matrix & 2y-SSM \\
\hline 2y-SSM & 1 \\
CHLOROA 9-9 & 0.011 \\
PHEO 9-9 & -0.009 \\
SALI 9-9 & -0.177 \\
TEMP 9-9 & 0.087 \\
TURB 9-9 & -0.043 \\
CHLOROA 3-6 & 0.040 \\
PHEO 3-6 & 0.081 \\
SALI 3-6 & -0.125 \\
TEMP 3-6 & 0.007 \\
TURB 3-6 & -0.041 \\
CHLOROA 3-9 & 0.043 \\
PHEO 3-9 & 0.054 \\
SALI 3-9 & -0.157 \\
TEMP 3-9 & -0.010 \\
TURB 3-9 & -0.015 \\
CHLOROA 12-6 & 0.002 \\
PHEO 12-6 & 0.033 \\
SALI 12-6 & -0.136 \\
TEMP 12-6 & 0.054 \\
TURB 12-6 & -0.055 \\
CHLOROA 6-9 & 0.067 \\
PHEO 6-9 & 0.050 \\
SALI 6-9 & -0.172 \\
TEMP 6-9 & -0.130 \\
TURB 6-9 & 0.047 \\
CHLOROA 9-3 & $-\mathbf{0 . 1 9 4}$ \\
PHEO 9-3 & -0.038 \\
SALI 9-3 & -0.217 \\
TEMP 9-3 & 0.088 \\
TURB 9-3 & 0.002 \\
CHLOROA 12-3 & -0.138 \\
PHEO 12-3 & -0.036 \\
SALI 12-3 & -0.147 \\
TEMP 12-3 & 0.140 \\
TURB 12-3 & -0.040 \\
\hline & \\
&
\end{tabular}

*In bold, significant correlations to the $p<0.005$ level

\begin{tabular}{|c|c|}
\hline Legend & \\
\hline $2 y-S S M$ & 2 -year-old oysters spring and summer mortality \\
\hline $1 y$-SSM & 1-year-old oysters spring and summer mortality \\
\hline \begin{tabular}{|l|} 
CHLOROA 9-9 \\
\end{tabular} & mean chlorophyll a from september $\mathrm{n}-1$ to september $\mathrm{n}$ \\
\hline PHEO 9-9 & mean pheophytin from september $\mathrm{n}-1$ to september $\mathrm{n}$ \\
\hline SALI 9-9 & mean salinity from september $n-1$ to september $n$ \\
\hline TEMP $9-9$ & mean temperature from september $n-1$ to september $n$ \\
\hline TURB 9-9 & mean turbidity from september $n-1$ to september $n$ \\
\hline CHLOROA 3-9 & mean chlorophyll a from march $n$ to september $n$ \\
\hline $\begin{array}{l}\text { PHEO 3-9 } \\
\text { SALI 3-9 }\end{array}$ & $\begin{array}{l}\text { mean pheophytin from march } n \text { to september } n \\
\text { mean salinity from march } n \text { to september } n\end{array}$ \\
\hline TEMP 3-9 & mean temperature from march $n$ to september $n$ \\
\hline TURB 3-9 & mean turbidity from march $n$ to september $n$ \\
\hline \begin{tabular}{|l|} 
CHLOROA 9-3 \\
\end{tabular} & mean chlorophyll a from september $n-1$ to march $n$ \\
\hline PHEO 9-3 & mean pheophytin from september $n-1$ to march $n$ \\
\hline SALI 9-3 & mean salinity from september $n-1$ to march $n$ \\
\hline TEMP 9-3 & mean temperature from september $n-1$ to march $n$ \\
\hline TURB 9-3 & mean turbidity from september $n-1$ to march $n$ \\
\hline \begin{tabular}{|l|} 
CHLOROA3-6 \\
\end{tabular} & mean chlorophyll a from march $n$ to june $n$ \\
\hline PHEO 3-6 & mean pheophytin from march $n$ to june $n$ \\
\hline SALI 3-6 & mean salinity from march $n$ to june $n$ \\
\hline TEMP $3-6$ & mean temperature from march $n$ to june $n$ \\
\hline TURB 3-6 & mean turbidity from march $n$ to june $n$ \\
\hline CHLOROA 12-3 & mean chlorophyll a from december $n-1$ to march $n$ \\
\hline PHEO 12-3 & mean pheophytin from december $n-1$ to march $n$ \\
\hline SALI 12-3 & mean salinity from december $n-1$ to march $n$ \\
\hline TEMP $12-3$ & mean temperature from december $n-1$ to march $n$ \\
\hline TURB 12-3 & mean turbidity from december $n-1$ to march $n$ \\
\hline CHLOROA 12-6 & mean chlorophyll a from december $n-1$ to june $n$ \\
\hline PHEO 12-6 & mean pheophytin from december $n-1$ to june $n$ \\
\hline SALI 12-6 & mean salinity from december $n-1$ to june $n$ \\
\hline TEMP $12-6$ & mean temperature from december $n-1$ to june $n$ \\
\hline TURB 12-6 & mean turbidity from december $n-1$ to june $n$ \\
\hline CHLOROA 6-9 & \\
\hline PHEO 6-9 & mean pheophytin from june $\mathrm{n}$ to september $\mathrm{n}$ \\
\hline SALI 6-9 & mean salinity from june $n$ to september $n$ \\
\hline $6-9$ & perature from june $n$ \\
\hline & \\
\hline
\end{tabular}


Table 8

One-year-old oysters summer mortality (1y-SSM)

Adjustment coefficents

\begin{tabular}{ll}
\hline$R$ & 0.346 \\
$R^{2}$ & 0.119 \\
$R^{2}$ aj. & 0.109 \\
SCR & 0.779 \\
\hline
\end{tabular}

Evaluation of the value of the information brought by the variables $(\mathrm{H} 0=\mathrm{Y}=\operatorname{Moy}(\mathrm{Y}))$ :

\begin{tabular}{lccccc}
\hline \multicolumn{1}{c}{ Source } & $\mathrm{df}$ & Sum of squares & Mean square & $\mathrm{F}$ - Fisher & $\mathrm{Pr}>\mathrm{F}$ \\
\hline Model & 1 & 0.106 & 0.106 & 11.941 & 0.001 \\
Error & 88 & 0.779 & 0.009 & & \\
Total & 89 & 0.884 & & & \\
\hline
\end{tabular}

Model analysis (Type III SS) :

\begin{tabular}{|c|c|c|c|c|c|c|}
\hline Source & $\mathrm{df}$ & Sum of squares & Mean square & $\bar{F}$ - Fisher & $\operatorname{Pr}>\mathrm{F}$ & \\
\hline CHLOROA 6-9 & 1 & 0.106 & 0.106 & 11.941 & 0.001 & \\
\hline \multicolumn{7}{|c|}{ Model parameters } \\
\hline Parameter & Value & SD & t - Student & $\operatorname{Pr}>t$ & Lower limit $95 \%$ & Upper limit $95 \%$ \\
\hline Constant & 0.075 & 0.016 & 4.809 & $<0.0001$ & 0.044 & 0.107 \\
\hline CHLOROA 6-9 & 0 & 0.005 & 3.456 & 0.001 & 0.007 & 0.028 \\
\hline
\end{tabular}

Model equation : $1 \mathrm{y}-\mathrm{SSM}=7.54 .10^{-02}+1.75 .10^{-02}{ }^{*} \mathrm{CHLOROA} 6-9$

Two-year-old oysters summer mortality (2y-SSM)

Adjustment coefficents

\begin{tabular}{ll}
\hline$R$ & 0.404 \\
$R^{2}$ & 0.163 \\
$R^{2} a j$. & 0.139 \\
SCR & 0.499 \\
\hline
\end{tabular}

Evaluation of the value of the information brought by the variables $(\mathrm{HO}=\mathrm{Y}=\operatorname{Moy}(\mathrm{Y}))$ :

\begin{tabular}{lccccc}
\hline \multicolumn{1}{c}{ Source } & $\mathrm{df}$ & Sum of squares & Mean square & $\mathrm{F}$ - Fisher & $\mathrm{Pr}>\mathrm{F}$ \\
\hline Model & 3 & 0.097 & 0.032 & 6.743 & 0.000 \\
Error & 104 & 0.499 & 0.005 & & \\
Total & 107 & 0.596 & & & \\
\hline
\end{tabular}

Model analysis (Type III SS) :

\begin{tabular}{|c|c|c|c|c|c|c|}
\hline Source & $\mathrm{df}$ & Sum of squares & Mean square & F-Fisher & $\mathrm{Pr}>\mathrm{F}$ & \\
\hline SALI 9-3 & 1 & 0.020 & 0.020 & 4.180 & 0.043 & \\
\hline CHLOROA 9-3 & 1 & 0.069 & 0.069 & 14.344 & 0.000 & \\
\hline TEMP 9-9 & 1 & 0.035 & 0.035 & 7.339 & 0.008 & \\
\hline \multicolumn{7}{|c|}{ Model parameters } \\
\hline Parameter & Value & SD & $\mathrm{t}$ - Student & $\mathrm{Pr}>\mathrm{t}$ & Lower limit $95 \%$ & Upper limit $95 \%$ \\
\hline Constant & 0.161 & 0.222 & 0.729 & 0.468 & -0.278 & 0.601 \\
\hline SALI 9-3 & -0.010 & 0.005 & -2.045 & 0.043 & -0.020 & 0.000 \\
\hline CHLOROA 9-3 & -0.043 & 0.011 & -3.787 & 0.000 & -0.065 & -0.020 \\
\hline TEMP 9-9 & 0.022 & 0.008 & 2.709 & 0.008 & 0.006 & 0.038 \\
\hline
\end{tabular}

Model equation : $2 y-S S M=0.16-9.96 .10^{-03}{ }^{*}$ SALI 9-3 $-4.28 .10^{-02}{ }^{*} \mathrm{CHLOROA} 9-3+2.22 .10^{-02}{ }^{*}$ TEMP 9-9 


\section{Figure captions}

3 Figure 1. Mortality survey of Crassostrea gigas in 39 sites (black type) among which 11 where

4 environmental data are available (black type on gray circle, table 2), 20 "farming areas"

5 (white type and dotted lines) and 9 coastal areas: Normandy, Nomano-breton Gulf and

6 North of Finistere on Eng lish Channel coast, Mor Bras, Pays de Loire, Re Island, Marennes-

7 Oléron Bay and Aquitaine on the French Atlantic coast and Languedoc on Mediterranean

8 sea. Farming areas: Veys bay(BV), Saint Vaast-La-Hougue bay (SV), West of Cotentin (CO),

9 Cancale bay $(C A)$, Paimpol bay (PL), Morlaix bay (MX), Aber Benoit (AB), Brest roadstead

10 (BR), Etel river (EL), Quiberon bay (QB), Auray river (AY), Gulf of Morbihan (GM), Penerf

11 bay (PF), Pen-Bé bay (PB), Bourgneuf bay (BO), Ré island (RE), North part of Marennes-

12 Oléron bay (NM), South part of Marennes-Oléron bay (SM), Arcachon basin (AR), Thau

13 lagoon $(\mathrm{TH})$.

14

15 Figure 2. Mortality rate of one- and two-year-old oysters on French coasts between 1995 and

162005 (one-year-olds) or 1993 and 2005 (two-year-olds). Coastal areas : Veys bay (BV),

17 Saint Vaast-La-Hougue bay (SV), West of Cotentin (CO), Cancale bay (CA), Paimpol bay

18 ( $P L)$, Morlaix bay (MX), Aber Benoit (AB), Brest roadstead (BR), Etel river (EL), Quiberon

19 bay (QB), Auray river (AY), Gulf of Morbihan (GM), Penerf bay (PF), Pen-Bé bay (PB),

20 Bourgneuf bay (BO), Ré island (RE), North part of Marennes-Oléron bay (NM), South part of

21 Marennes-Oléron bay (SM), Arcachon basin (AR), Thau lagoon (TH).

23 Figure 3. Mortality rate for one-year-old (A) and two-year-old (B) oysters, according to the 24 rearing sites. Distribution of the mean monthly values in quartiles (Box and Whisker plot 25 presentation). Farming areas : Veys bay (BV), Saint Vaast-La-Hougue bay (SV), West of 26 Cotentin (CO), Cancale bay (CA), Paimpol bay (PL), Morlaix bay (MX), Aber Benoit (AB), 27 Brest roadstead (BR), Etel river (EL), Quiberon bay (QB), Auray river (AY), Gulf of Morbihan 28 (GM), Penerf bay (PF), Pen-Bé bay (PB), Bourgneuf bay (BO), Ré island (RE), North part of 29 Marennes Oléron bay (NM), South part of Marennes-Oléron bay (SM), Arcachon bas in (AR), 30 Thau lagoon (TH). 
33 Figure 4. Seasonal and hydrological characteristics of the oyster culture sites along the French 34 coasts. General PCA with the descriptors (turbidity, ......). The numbers ' 1 ' and ' 12 ' refer to 35 months of the year. To improve typology, coastal areas are presented separately : Veys 36 bay (BV), Cancal bay (CA), Paimpol bay(PL), Morlaix bay (MX), Brest roadstead (BR),

37 Quiberon bay (QB), Bourgneuf bay (BO), North part of Marennes-Oléron bay (NM), South 38 part of Marennes-Oléron bay (SM), Arcachon basin (AR), Thau lagoon (TH).

40 Figure 5. Principal Component Analyses variables representations (summer mortality of oysters 41 and environmental parameters) ; A : One-year-old oysters summer mortality (labelled 1y-SM) 42 and environmental parameters (CHLOROA, PHEO, SALI, TURB, TEMP) ; B : Two-years-old 43 oysters summer mortality (labelled 2y-SM) and environmental parameters (CHLOROA, 44 PHEO, SALI, TURB, TEMP) 


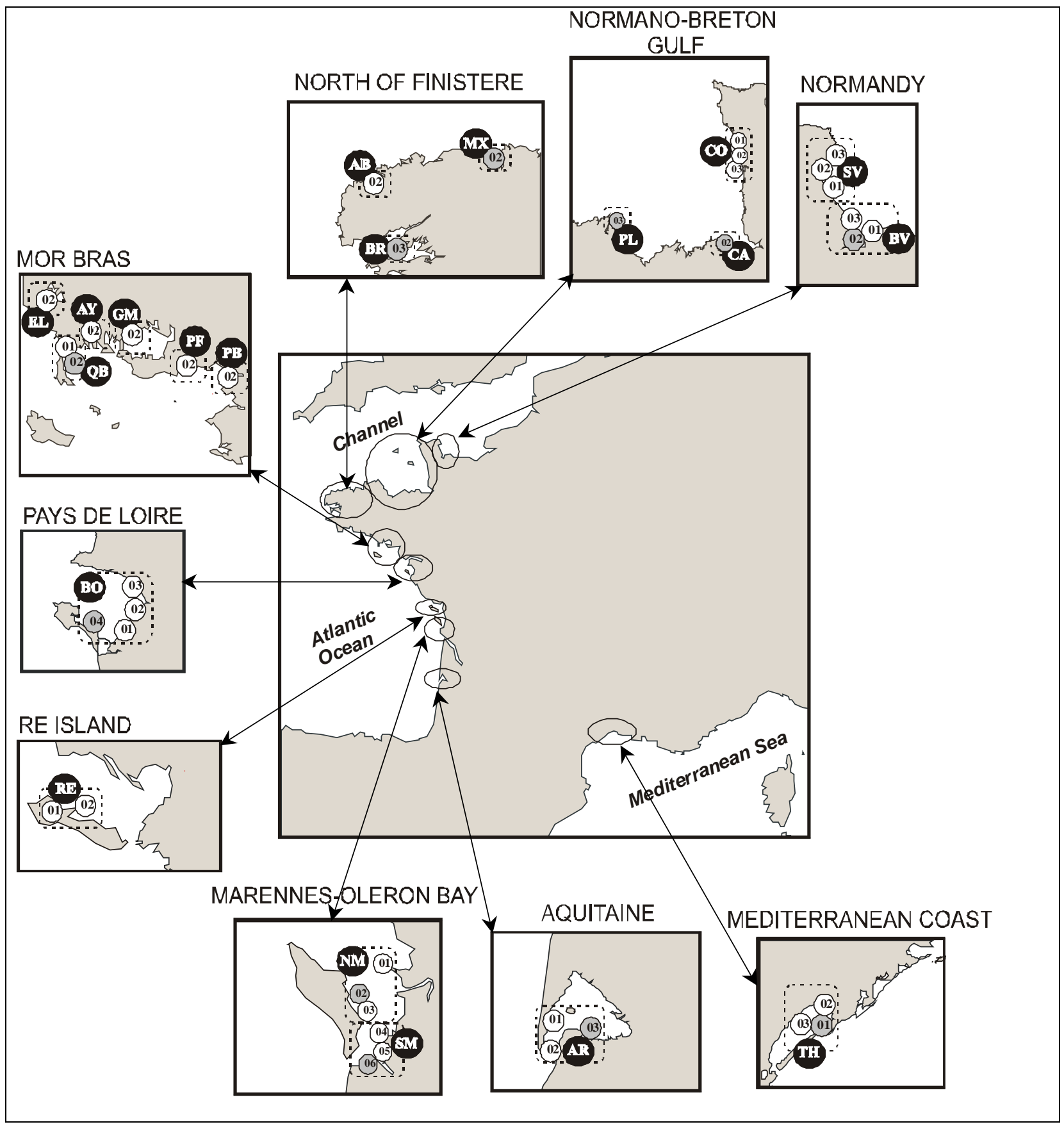

Figure 1 


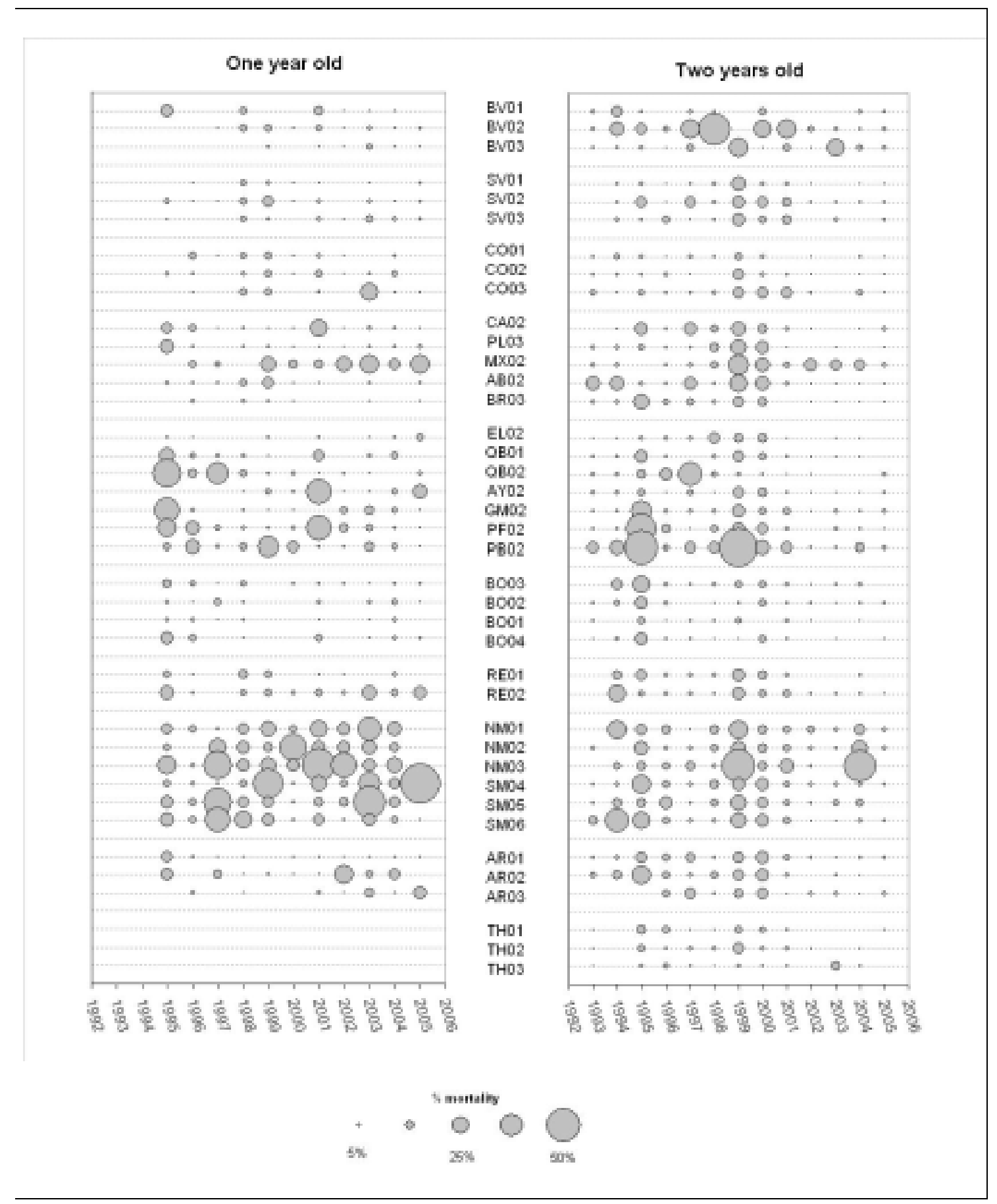

Figure 2 


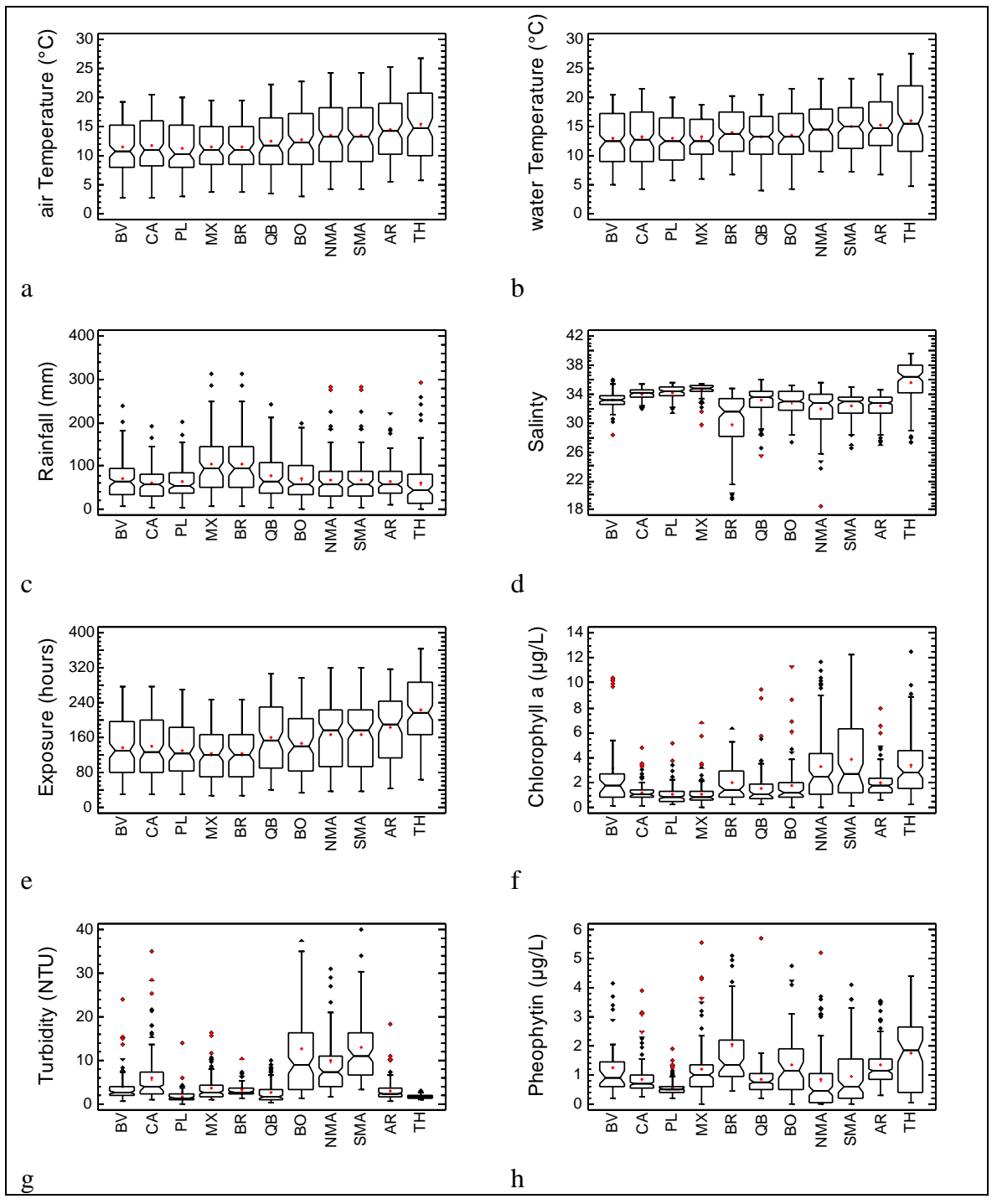

Figure 3 


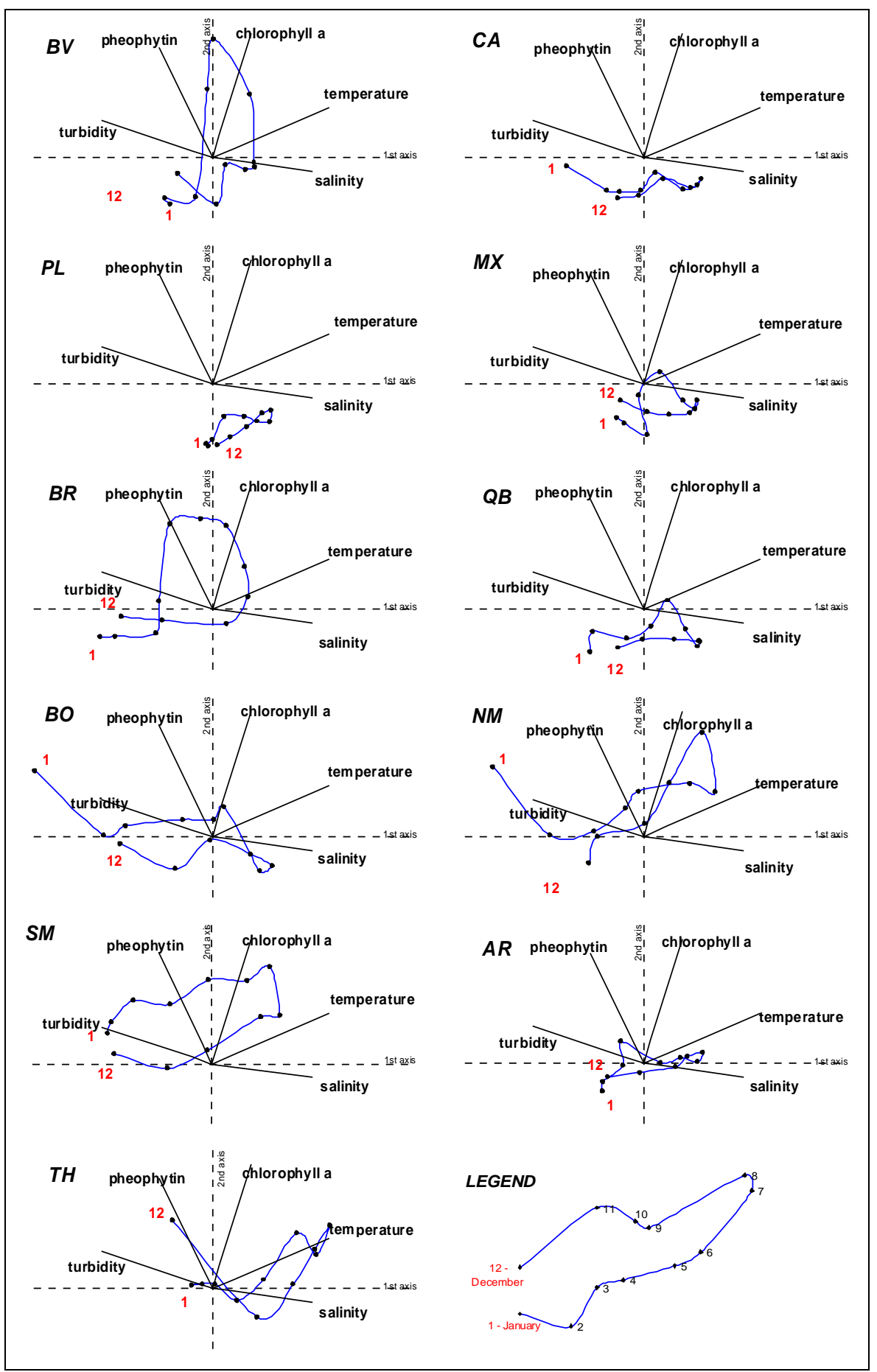

Figure 4 


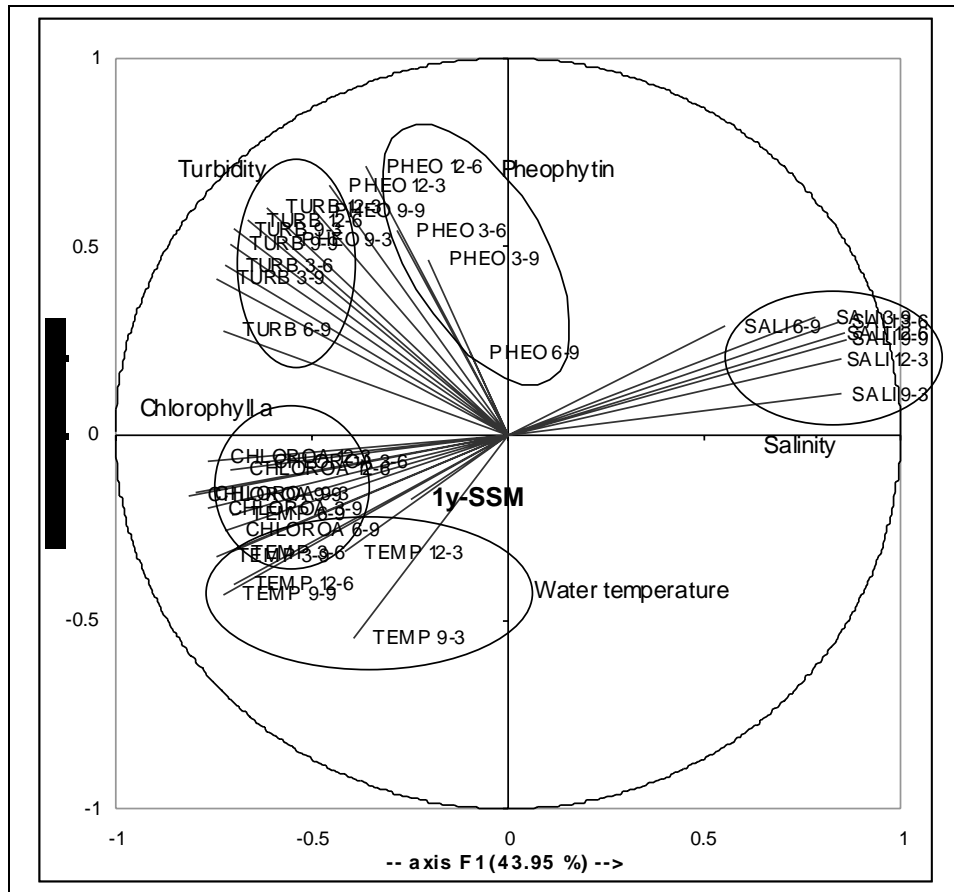

A

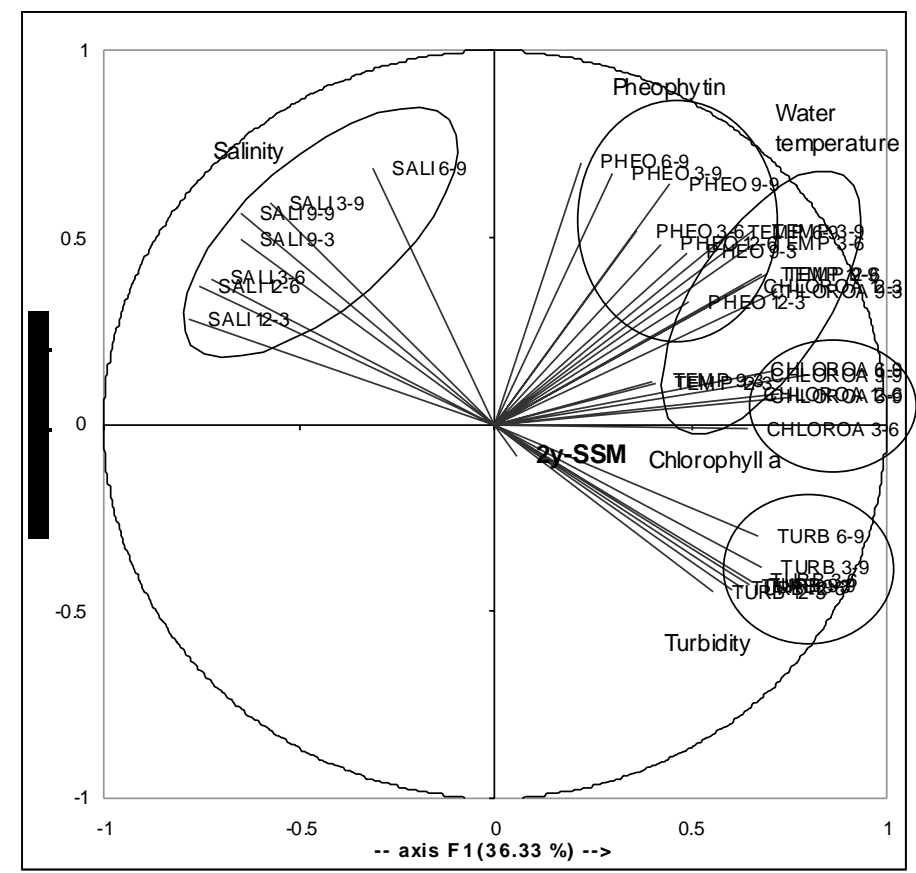

B

Figure 5 


\section{Response to reviewers (Manuscript AQUA-D-06-0007)}

Dear reviewers,

We have considered and taken into account many of your remarks.

We have taken the opportunity of this revision to add two years, available from the two monitoring bases, environment (Rephy) and mortality (Remora) : the new period is so 19932005. As you '1l see, the main factors correlated to mortalities remain unchanged.

We also focused on the explanatory seawater parameters CHLOROA, SALI, PHEO, TEMP, TURB, instead of more external parameters like meteorology (only considered graphically).

We have tried to redefine and present more clearly the three geo graphic levels : 9 coastal areals, 20 farming areas, and 39 sites (11 of which are documented environmentally) . Doing so, we realized a slight change in the limits of the 9 "coastal areas" (west Cotentin grouped with North-East Brittany) which looks more rationale, ecologically.

Concerning the statistical analysis :

- the method of "autocorrelations" seemed to us less adapted than standard PCAs and multiple regressions.

- the analyses coupling environmental data (grouped systematically by 3, 6, 9 or 12 months) and mortality have been redone completely. The PCAs allow to describe globally the relations between variables. Multiple regressions are based on a "progressive regression" that combines ascendant and descendant stepwise regression.

Finally, no factor alone explains much of the mortalities, and the ways of action are not always clear, but this crossing between independent monitoring data bases looked seemed to us useful.

Regards

J. Mazurie 